\title{
Trade Liberalization and the Environment in Vietnam
}

\author{
Muthukumara Mani ${ }^{1}$ \\ and \\ Shreyasi Jha
}

Vietnam's integration with the international economy has increased significantly over the past decade, aided by substantial liberalization of trade, and appears set to increase further as trade-expanding measures take full effect. This rather dramatic shift in Vietnam's trading patterns has important implications for the environment and use of natural resources. This paper offers a systematic analysis of the trading and investment patterns to give a broader understanding of the environmental implications of greater openness of the economy during the last decade. The results suggest increasing manufacturing and export activity in water and toxic pollution-intensive sectors compared to the less pollution-intensive sectors. The story is, on the surface, consistent with the changing composition of Vietnamese production and exports away from traditional sectors and towards pollution-intensive manufacturing (especially leather and textiles). The paper also highlights the need to consider strengthening environmental policies while further trade liberalization is being contemplated through Vietnam's joining of the WTO.

World Bank Policy Research Working Paper 3879, April 2006

The Policy Research Working Paper Series disseminates the findings of work in progress to encourage the exchange of ideas about development issues. An objective of the series is to get the findings out quickly, even if the presentations are less than fully polished. The papers carry the names of the authors and should be cited accordingly. The findings, interpretations, and conclusions expressed in this paper are entirely those of the authors. They do not necessarily represent the view of the World Bank, its Executive Directors, or the countries they represent. Policy Research Working Papers are available online at http://econ.worldbank.org.

\footnotetext{
${ }^{1}$ This was prepared as a background paper for Vietnam Country Environment Analysis. Muthukumara Mani is a Senior Environmental Economist in Environment Department of the World Bank and Shreyasi Jha is an Assistant Professor at LBJ School of Public Affairs, University of Texas at Austin. We are grateful for comments received on an earlier draft from Sushenjit Bandyopadhyay, Richard Damania, Per Fredricksson, Kirk Hamilton, Mahvash Qureshi and Vivek Suri.
} 


\section{INTRODUCTION}

Trade liberalization and export promotion have been central to Vietnam's continuing economic transition. To this end, Vietnam has pursued a multi-pronged approach to gradually reducing trade barriers and increasing the outward orientation of the economy. Vietnam's economy has doubled in size during the last decade, while its poverty rate has halved; exports are growing by 20 percent per year (substantially faster than GDP), and foreign direct investment (FDI) inflows by 10 percent per year.

Vietnam's commitment to trade liberalization has been fueled, to a large extent, by bilateral and multilateral trade agreements. Under the ASEAN Free Trade Agreement (AFTA, 1995), tariffs on imports from ASEAN countries were reduced to below 20 percent and are targeted to be below 5 percent by 2006. Under the United StatesVietnam Bilateral Trade Agreement (USBTA, 2001), Vietnam made substantial further commitments to liberalize its trade regime, including tariff reduction and removal of quota restrictions. Other trade reform measures that Vietnam has committed to under the USBTA include improving transparency in its trade laws, introducing dispute settlement procedures, protecting intellectual property, and facilitating investment. USBTA provided a sizable fillip to exports since it became effective, with exports to the U.S. increasing by 128 percent and accounting for 82 percent of total export growth in 2002, making U.S. the largest market for Vietnamese exports ${ }^{2}$. Currently, Vietnam is vying for membership in the World Trade Organization (WTO) which requires a commitment to simplify import controls and reduce the level of import protection.

The composition of Vietnam's exports and imports has also altered significantly during this period. While the share of crude oil in total exports declined from a third in the early 1990s to a fifth by 2002, manufacturing exports rose from 6 percent to 32 percent (see Figure 1). There has been a significant diversification in Vietnam's export markets as well. With Vietnam becoming less dependent on oil exports, Japan and Singapore have become less important as destinations for Vietnam's exports. The EU and U.S. have

\footnotetext{
${ }^{2}$ IMF (2003).
} 
overtime become major markets for Vietnam's exports of manufactured goods such as textiles, garments, and footwear (see Figure 2). The degree of concentration of trading partners, as measured by the Herfindahl Index, declined from 0.18 in 1992 to 0.11 in 2002 (IMF, 2003). ${ }^{3}$

\section{Figure 1. Vietnam's Export Structure by Sector}

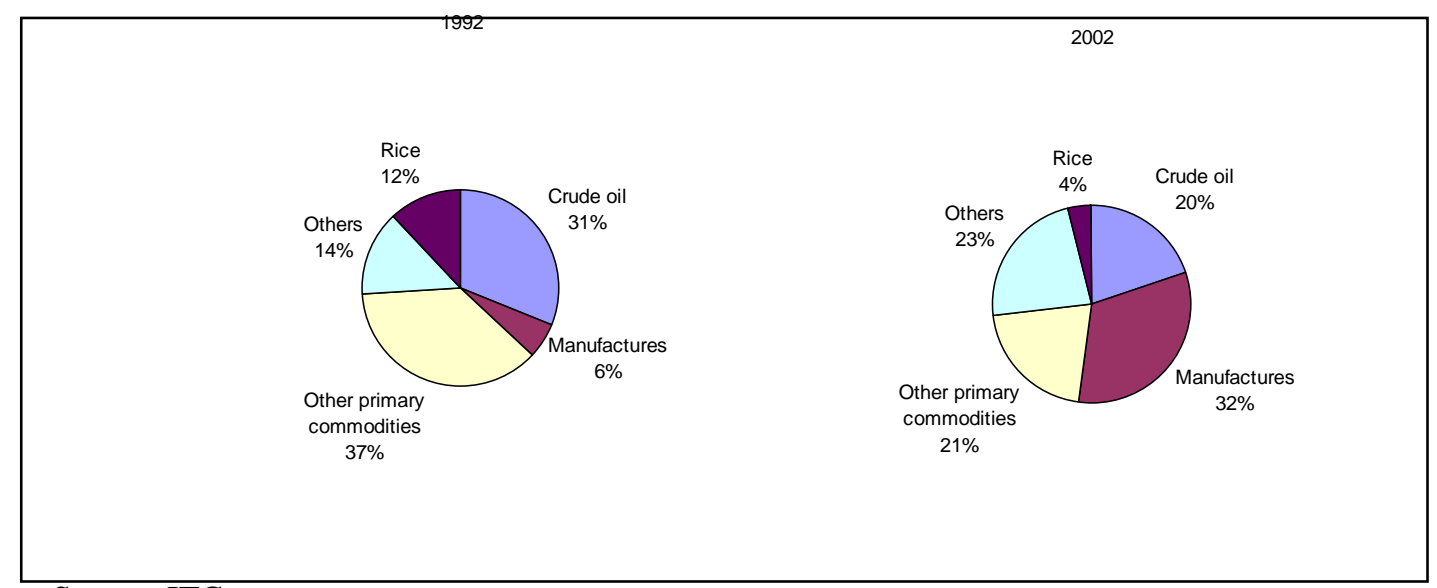

Source: ITC

Figure 2. Vietnam's Export Structure by Country/Region

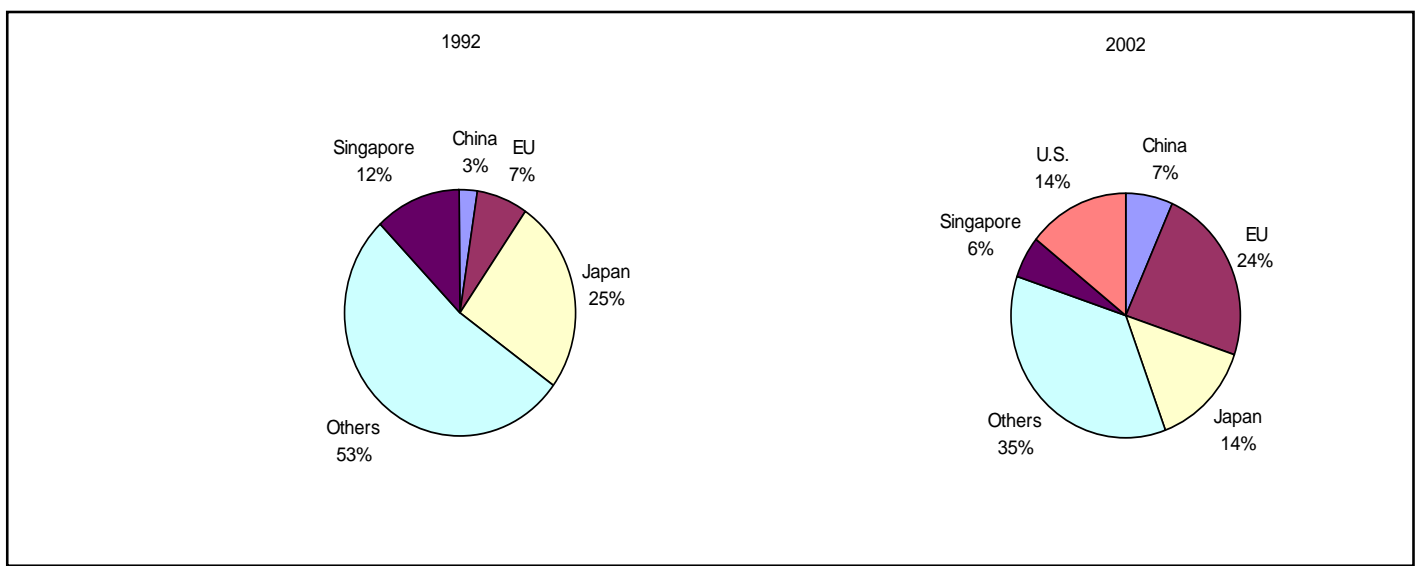

Source: IMF Direction of Trade Statistics

Because of the linkages between trade and the environment (through scale, composition and technique effects), this rather dramatic shift in Vietnam's trade patterns could have important implications for the environment and use of natural resources. Though the precise environmental impacts of the various bilateral, regional, or multilateral trade

3 The Herfindahl Index is the sum of the squared market shares of all trading partners; a decrease indicates reduced concentration or increased diversification. 
liberalization programs undertaken are often difficult to anticipate, a systematic analysis of the trade and investment patterns could give us a broad understanding of the environmental implications of greater economic openness. This would provide useful guidance for integrating environmental concerns in macroeconomic and sectoral policy making, especially as Vietnam plans further trade liberalization under the WTO.

The remainder of this paper is organized as follows. Section II outlines the general tradeenvironment debate in the literature. Section III outlines the basic model and hypothesis to be tested. Section IV describes the sample and data, and Section V provides empirical evidence in support of the predictions of the model. Section VI concludes the paper with a discussion of the results and their implications.

\section{THE TRADE-ENVIRONMENT DEBATE}

Environmentalists and the trade policy community have been engaged in a heated debate over the last decade or so over the environmental consequences of liberalized trade. This debate intensified with the creation of the World Trade Organization and the subsequent commencement of Doha round of trade negotiations and initially, was quite contentious and unproductive, as both parties differed greatly in their trust of market forces and typically value the environment differently. ${ }^{4}$ Free traders feared that environmental protection will be used as an excuse by some economic sectors to gain protection against competition from abroad. Environmentalists feared that free trade will be used as an excuse to give inadequate weight to environmental goals and excessive weight to maximization of market-measured GDP. The importance of establishing coherent relationships between the trade obligations set out in various bilateral/multilateral trade agreements and environmental policies of countries is increasingly being recognized. ${ }^{5}$

${ }^{4}$ Copeland and Taylor, 2004.

${ }^{5}$ A number of bilateral agreements have gone beyond the WTO to give attention to environmental protection aspects. Agreements such as the North American Free Trade Agreement (NAFTA) and USSingapore FTA directly address environmental concerns, and Regional Economic Integration Organizations (e.g. MERCOSUR) deal with trade-environment issues more both in relations between their members and in global policy activities. A number of countries that recently joined the EU and the ones that are aspiring to join the EU have to meet certain clear-cut environmental policy requirements of the EU. 
The concerns with environmental implications of trade involve both the domestic implications of policy reforms as well as the global environmental dimension of bilateral and multilateral trade agreements. Although liberalizing reforms generally promote more efficient resource use (including use of environmental resources), in practice there is no clear-cut reason to expect that trade liberalization will be either good or bad for the environment. Nonetheless, some of the common concerns often highlighted are:

- Reducing barriers to trade will reinforce the tendency for countries to export commodities that make use of resource-intensive production factors. As a result of weak environmental policies, trade liberalization in developing countries may result in shifts in the composition of production, exports, and FDI to more pollution or resource intensive sectors.

- Trade liberalization may directly affect environmental standards. Intensified competition could lead to a "race to the bottom" as governments lower standards in the hope of giving domestic firms a competitive edge in world markets or attracting foreign investment.

- "Environmental tariffs" may be employed against trading partners deemed to have inadequate environmental standards. The risk being that these will be used as disguised protection for domestic firms.

In practice, however, the opposite often seems to have been the case. More open trade improves growth and economic welfare and is in itself could take some pressure on the environment by making more resources available for environmental protection. Increased real income is also often associated with increased demand for environmental quality. Countries that are more open to trade seem to adopt cleaner technologies more quickly (WTO, 2004). Greater openness to trade also encourages cleaner manufacturing because protectionist countries tend to shelter pollution-intensive heavy industries (World Bank, 2000). It is often the case that pressures on the environment and natural resources-incentives to over-exploit or deplete resources, however, are more directly 
related to policies and institutions within the sector than to trade openness per se (World Bank, 1999).

\section{HYPOTHESES AND SPECIFICATION}

\section{a. Hypotheses}

In general, trade liberalization can affect the environment through several mechanisms, such as inter-jurisdictional competition to lower standards, transfer of pollution abatement technology, cross-border spillovers, or changes to the overall scale of economies. The various effects of trade on environmental quality can be divided into three components: how trade affects the overall scale of the economy; how trade affects the techniques of production, and how trade affects the composition of industries (Copeland and Taylor, 2003). But the most direct effect of trade liberalization on the environment would be through the composition of industries and hence much of the focus of the literature has been on dissecting the composition effects of trade. Trade liberalization leads to specialization, and countries that specialize in less (more) pollution-intensive goods will have cleaner (dirtier) environments.

Given Vietnam's comparative advantage in labor-intensive goods and relatively weaker environmental regulations compared to its main trading partners (such as Japan and EU), there is concern that as Vietnam continues to expand its international trade it may be specializing in pollution intensive industries. The primary objective of this study is to examine the composition effect of trade liberalization in Vietnam and form policy recommendations relating to its trade and environmental policies. ${ }^{6}$ A retrospective analysis of Vietnam's experience with partial trade liberalization (as a result of its participation in the AFTA and the USBTA) in the past few years will enable us to provide policy recommendations to reduce potential negative effect on the environment as Vietnam prepares to join the WTO later this year, and as the AFTA comes into full effect. While the trade obligation under the WTO are more comprehensive than the

\footnotetext{
${ }^{6}$ Composition effect measures the increase in pollution that is likely to result as a result of a change in composition of output and exports, following a move towards free trade.
} 
AFTA and the USBTA, a study of the environmental effects of Vietnam's experience with partial trade liberalization would nonetheless provide interesting insights about the trade-environment nexus in Vietnam.

A priori, the effect on the composition of production within Vietnam in response to trade liberalization is unclear. The composition of production will depend on how the supply costs of the producers in more polluting industries changes relative to those in less polluting industries as a result of trade liberalization. Based on 'traditional' factor endowments such as capital and labor, Vietnam's comparative advantage is in laborintensive production. If less strict environmental policies do influence production decisions, 'environment' can be considered a non-traditional factor of production, and Vietnam may have an advantage in pollution-intensive production. However, prior to trade liberalization measures that came into effect in the late 1990s, trade barriers and investment restrictions in manufacturing industries may have skewed the relative supply costs of producers and led producers to allocate resources into industries other than those dictated by traditional and non-traditional factor endowments.

Since 1997, however, effective rates of protection (ERP) have declined across all manufacturing industries ${ }^{7}$. As a result of increasing economic openness, domestic and foreign investors could invest in almost all manufacturing industries. As documented earlier in this paper, output and exports have increased during this period. This opening up of the economy through a reduction in trade restrictions and the selective removal of investment restrictions would influence the supply costs of producers leading to possible change in the composition of production and export.

We begin therefore by examining the degree to which the composition of Vietnam's manufacturing output has shifted towards clean or dirty sectors, and how much of that shift can be explained by changes in the composition of exports. ${ }^{8}$ Figures 3 and 4 show

\footnotetext{
${ }^{7}$ P. Athukorala (2005).

${ }^{8}$ In order to isolate this composition effect, we need a metric with which to label various industries are being relatively “clean” or “dirty.” To that end, we rely on the World Bank’s “Industrial Pollution
} 
Vietnam's output, exports and pollution intensity as measured by the pollution content of its manufacturing, between 1997-2002. We find that output took off after the gradual liberalization under AFTA and USBTA, increasing by about 12 percent between 1997 and 2002. On the other hand, average predicted pollution was roughly constant over this time period suggesting that the there was no dramatic shift in the composition of manufacturing towards cleaner or dirty sectors. However, if we break down the pollution intensity by media, we find that predicted air pollution grew by 8 percent, water pollution by 18 percent and toxic pollution by 13 percent. This suggests that production became more water pollution intensive and less air pollution intensive during this time indicating a slight shift in the composition of industries away from those that are responsible for air pollution and towards those which pollute the water more.

Figure 3: Overall Manufacturing Output and Pollution Intensity, 1997-2002 (in BVD, in 1994 constant dollars)

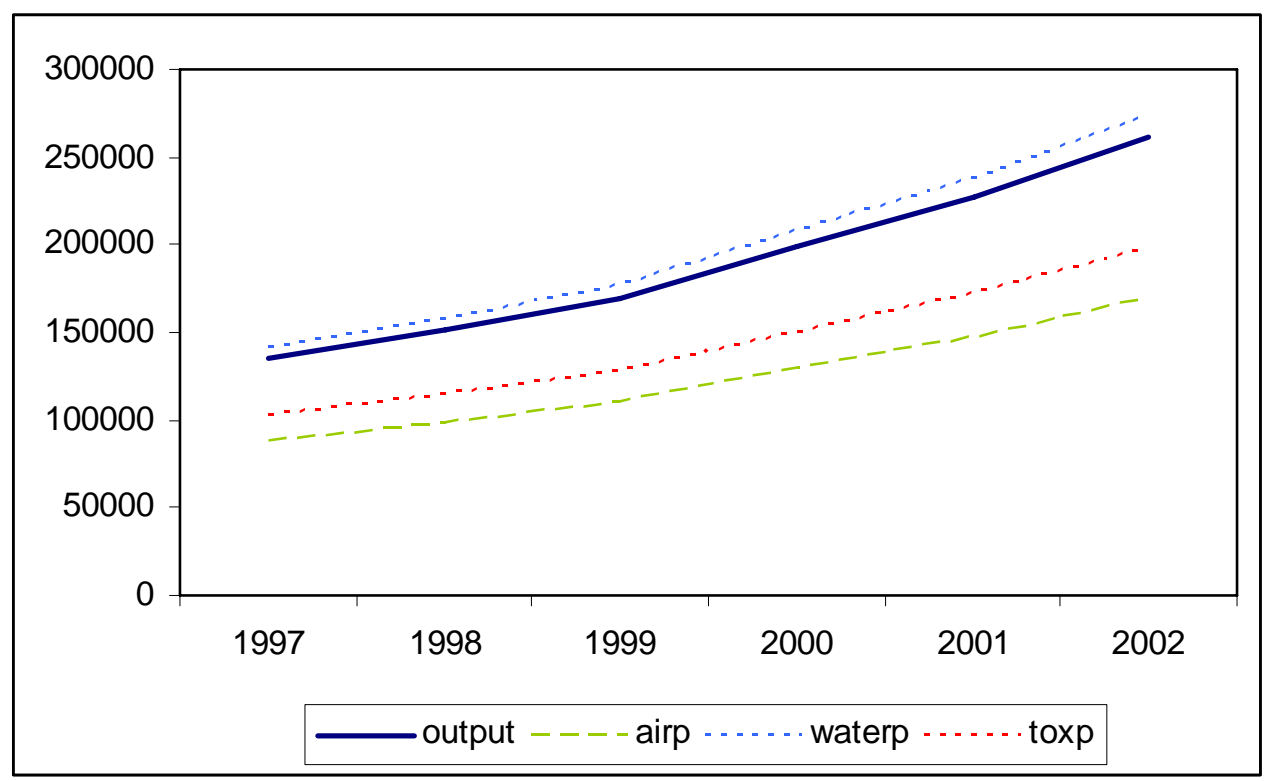

Source: GSO, Vietnam and World Bank IPPS

On the other hand, manufacturing exports increased by 100 percent during the same period (Figure 4). Disaggregated pollution intensity of exports by source shows that

Projection System (IPPS).” The predicted pollution levels are calculated by multiplying each 3-digit manufacturing industries output by the industry's IPPS coefficient, and then summing across industries to get total predicted pollution (in emissions per \$ output produced) for each year for each media. In the case of export, we multiply 3-digit manufacturing exports by the industry’s IPPS coefficient to obtain the predicted exports from dirty and clean industries for each year. 
toxic pollution intensive exports grew at nearly the same rate as the increase in overall manufacturing exports. There was a 100 percent increase in toxic pollution intensive exports between 1997 and 2002. Water and air pollution intensive exports remained fairly constant. Thus we find that most of the predicted pollutants grew at the same rate or grew by slightly less than the exports suggesting that there was not any profound shift towards cleaner sectors.

In order to get a complete picture of the changes in composition of trade, we need to consider the changing pollution intensity of imports. The figure on pollution intensity of imports (Figure 5) shows dramatic changes in the composition of imports. Unlike exports, the greatest increase in pollution intensity of imports was in water pollution intensive imports which increased nearly three times over this period while overall imports doubled.

Figure 4: Overall Manufacturing Exports and Pollution Intensity, 1997-2002 (in 10,000 VD, in 1997 constant dollars)

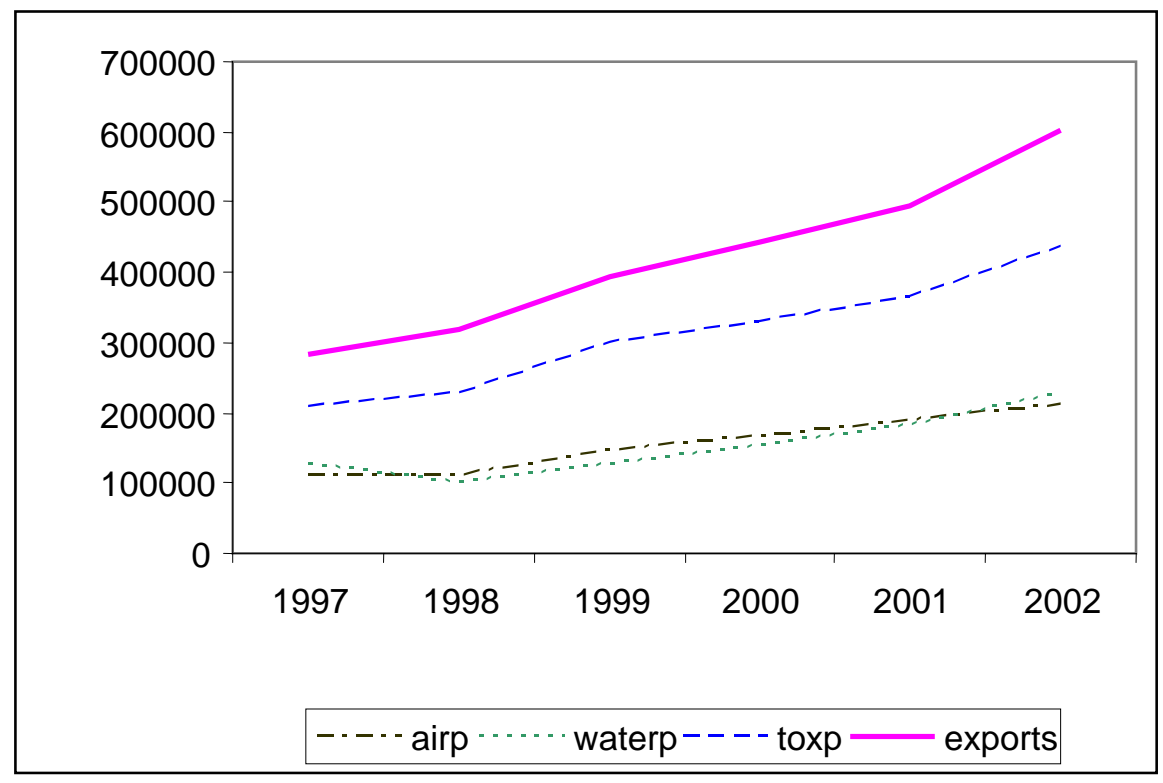


Figure 5: Overall Manufacturing Imports and Pollution Intensity, 1997-2002 (in 10,000 VD, in 1997 constant dollars) ${ }^{9}$

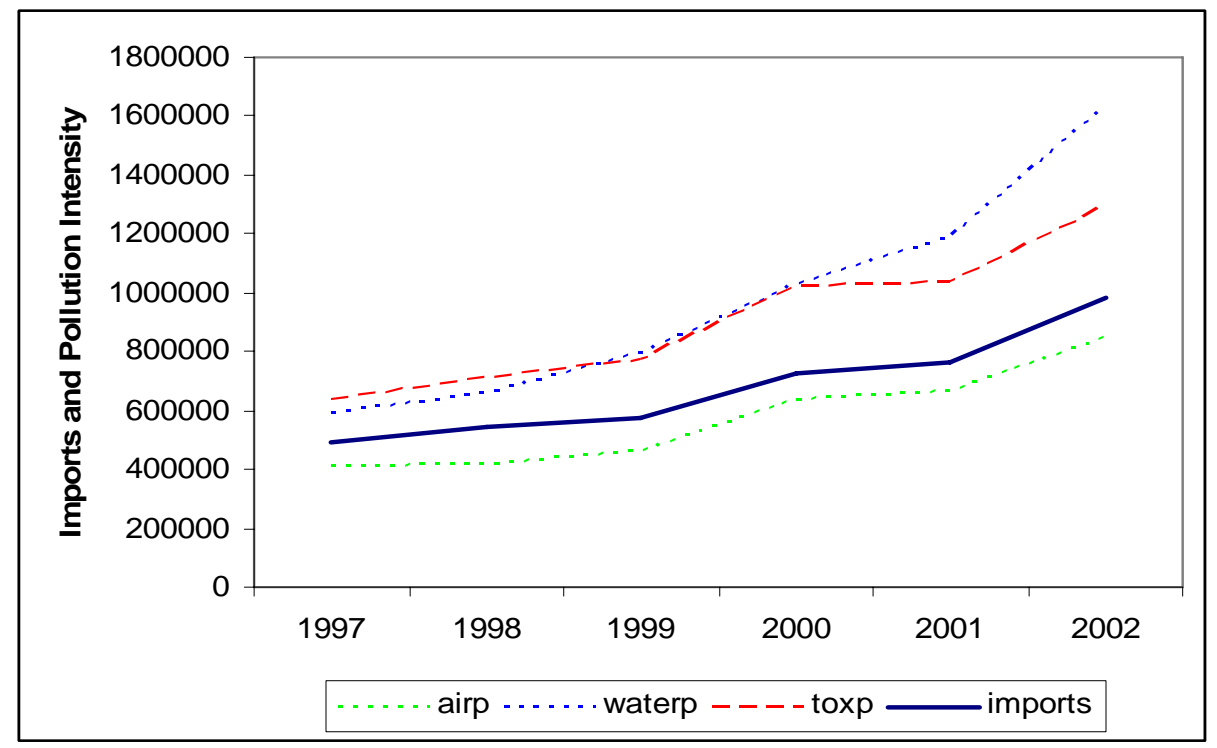

Together, the figures on output and import reveal that domestic output and imports from water pollution intensive sources increased during this period and may be indicative of an increase in domestic demand for water pollution intensive commodities and raw materials. Since the composition of exports depends on both domestic and international demand, we do not see similar trends in exports. Instead we see that Vietnamese toxic pollution intensive exports were higher than water and air pollution intensive exports. A possible reason for imports being dirtier than exports could be due the imports of intermediate goods that may have a higher pollution content.

Another way to look at industrial output and trade performance is to see how the various sectors have evolved in terms of their output and exports. Manufacturing industries can be classified into "clean” and "dirty" and their trends observed over a period of time. This would tell us whether there has been any trade-induced shift towards cleaner or dirtier production. Mani and Wheeler (1998) developed a classification to distinguish

\footnotetext{
${ }^{9}$ Note: the unit of measurement of exports and imports is 10,000 Vietnamese Dollars. We apply the IPPS coefficients to the exports and imports units to obtain the amount of pollution generated by media, in the same monetary units.
} 
dirty and clean industries and this has often been used in the literature. ${ }^{10}$ While this method is clearly not ideal, its strengths lies in the fact that the set of dirtiest manufacturing industries appears to be fairly stable across countries and pollutants. Figures 6 and 7 show the output (in BVD) and exports (in 10,000 VD), from 1997 to 2002, across dirty and clean industries in Vietnam. While the cleaner sectors have remained relatively clean we find that, within the dirty sectors, the water polluting ones have become relatively dirtier while air polluting ones have become relatively cleaner.

Figure 6: Dirty versus Clean Manufacturing Industries Pollution Intensity (kgs per BVD) 1997-2002

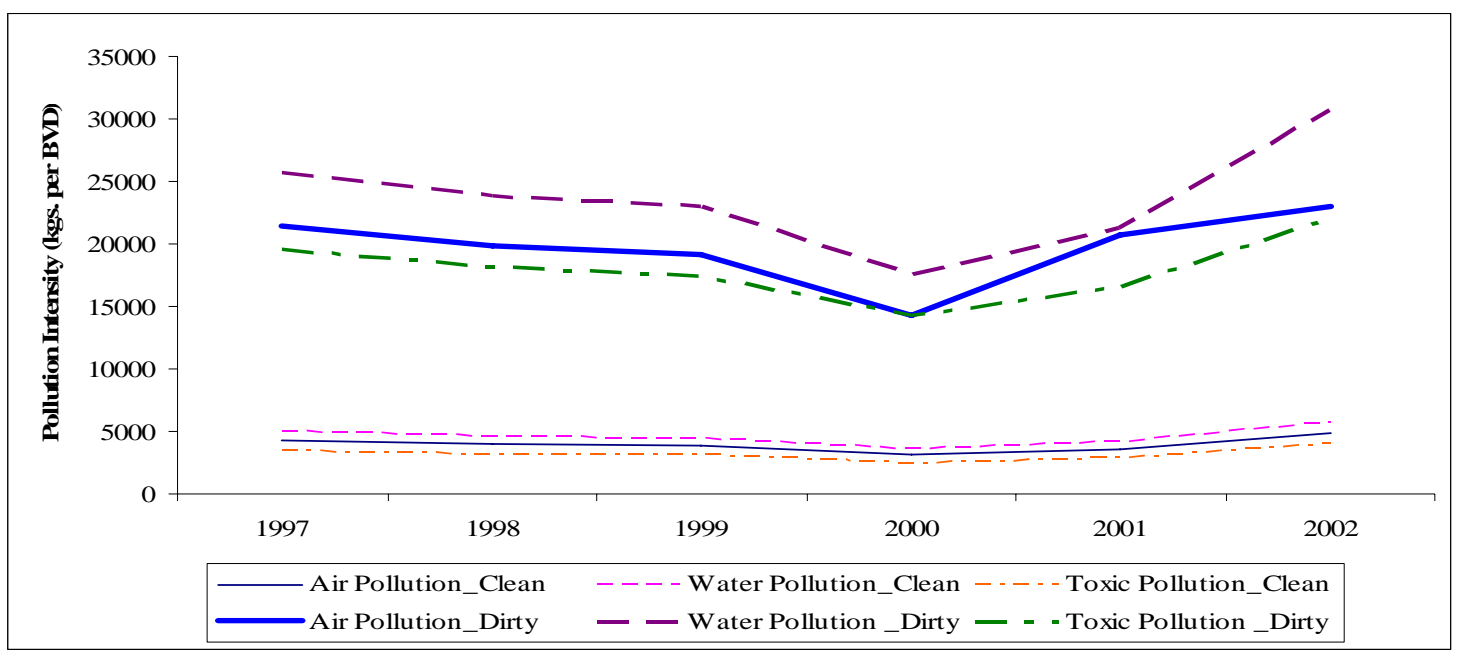

In terms of the output, both cleaner and dirty goods have kept pace with each other and in terms of exports, Vietnam's exports have not become dirtier as a result of trade openness and it seems to continue to be a net exporter of "clean" goods. But this evidence is only indirect. For more direct evidence we turn to a regression-based approach that controls for other factors that influence production and export decisions, and ask whether trade openness exacerbates the tendency for polluting industries to locate and/or expand due to lower domestic pollution abatement costs.

\footnotetext{
${ }^{10}$ The approach is based on categorizing industries on the basis of their emissions intensity (emissions per $\$$ of output) and computing average sectoral rankings for conventional air pollutants, water pollutants and toxic pollutants (Mani and Wheeler, 1998).
} 
Figure 7: Dirty versus Clean Manufacturing Industries Output (in BVD) and Exports (in 10,000 VD), 1997-2002

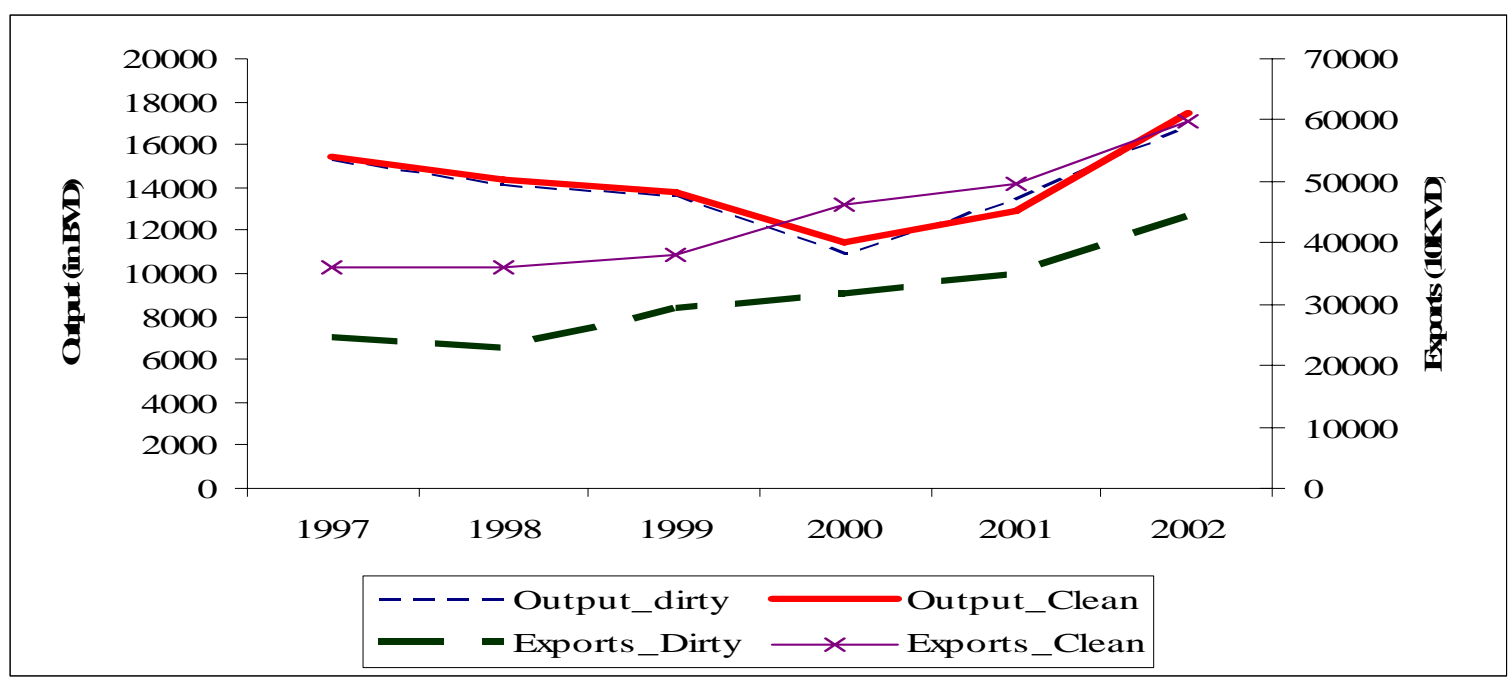

\section{b. Regression Approach}

Previous empirical studies on the relationship between trade and the environment have found varying results. Dean (2002) uses provincial level data on water pollution from China and found support for the idea that trade liberalization has both a direct and an indirect effect on emission growth and these could be opposite in sign. In contrast, Grossman and Krueger (1993) examined the environmental impacts of NAFTA and found no evidence that a comparative advantage is being created by lax environmental regulations in Mexico. Using data across different countries from 1960-1995, Mani and Wheeler (1999) found that 'pollution haven effects' are insignificant in developing countries because production is mainly for domestic consumption, not for export.

In a more closely related study, Gamper-Rabindran and Jha (2004) empirically analyzed the relationship between trade liberalization and the environment in the Indian context. Their findings indicate that exports and FDI grew in the more polluting sectors relative to the less polluting sectors between the pre and post liberalization periods. This evidence provides some support for concerns raised about the environmental impact of trade liberalization. Specifically, they find that trade liberalization has resulted in an increase in exports from industries that are more water and air pollution-intensive relative to less 
pollution-intensive ones. In addition, their analysis FDI inflows they suggest that foreign investments were higher in industries that were more intensive in air and water pollution.

While the situation in Vietnam differs in many respects from the Indian experience in terms of policy and scale of the economy, there are remarkable similarities in the history of their trade policies which were characterized by a long period of import-substitution, followed by rapid liberalization in a short period of time.

For this study, four hypotheses were tested using industry-level economic and environmental data for Vietnam:

1. Since 2000, Vietnam has become more specialized in the production from dirty industries relative to clean industries (the composition effect on domestic production).

2. As a result of the trade treaty with the US in 2000, Vietnam has become more specialized in share of exports from dirty industries relative to clean industries (composition effect on trade flows).

3. Since 1997, Vietnam has become more specialized in the exports from dirty industries relative to clean industries (the composition effect on exports).

4. There has been greater inflow of foreign investment into dirty industries relative to clean industries.

To test the first hypothesis, we measure whether domestic production has shown greater increase in dirty industries relative to clean industries between 2000 and 2002. Domestic production is a function of labor productivity (L), capital productivity (K), and pollution intensity (P). We use 2-digit Vietnam Standard Industrial Classification (VSIC) level data for manufacturing industries to examine if output has shown greater increase in the pollution intensive sectors compared to less pollution intensive sectors in the period following trade liberalization measures. The regression model is: 


$$
Y=\alpha+\beta_{1} L_{i t}+\beta_{2} K_{i t}+\beta_{3} P_{i t}+\mu_{i}+\varepsilon_{i t}
$$

where, $\mathrm{Y}$ is the net turnover in manufacturing industry $\mathrm{i}$ for time period $\mathrm{t}$ measured at the 2-digit VSIC level (there are total 22 3-digit VSIC manufacturing industries); $\mathrm{P}$ is industry-wise pollution intensity and $\mu$ is industry fixed effects. In addition to 22 industry level effects, we also used fixed effects for dirty and clean industries, using the Mani and Wheeler (1998) classification. Labor productivity (L) is the average net turnover per employee. Capital productivity $(\mathrm{K})$ is calculated by dividing the net turnover by the total stock of fixed capital. The coefficient of interest is $\beta_{3}$ which captures the increase in production of dirty industries relative to clean industries during the 2000-2002 period. If domestic production does shows an increase in the dirty industries relative to cleaner industries, we would find $\beta_{3}>0$. The results for equation (2) are presented in Table 2.

Second, we measure whether exports have increased in the dirty industries relative to clean industries between pre-2000 and post-2000 years (in the year 2000, USBTA came into effect). Based on Grossman and Krueger (1993), we estimate exports from Vietnam as a function of labor intensity (L), capital intensity (K), and pollution intensity (P). Similar to the specification of hypothesis 1, we use 2-digit VSIC level data for manufacturing industries to compare pre-2000 (1997-1999) with those immediately following trade liberalization (2001-2002). The regression model is:

$$
X_{i t}=\alpha+\gamma_{1} L_{i t}+\gamma_{2} K_{i t}+\gamma 3 P_{i t}+\gamma_{4}\left(P_{i t} * T_{t)}+\eta_{i}+\omega_{i t}\right.
$$

where, $\mathrm{X}$ is the export from industry $\mathrm{i}$ as a fraction of net turnover for time period $\mathrm{t}$ measured at the 2-digit VSIC level (there are total 22 3-digit VSIC manufacturing industries); $\mathrm{T}$ is the liberalization dummy that takes the value 1 for post-2000 years and 0 
otherwise; L is labor intensity, $\mathrm{K}$ is capital intensity, $\mathrm{P}$ is industry-wise pollution intensity and $\eta$ is industry fixed effects and $\omega$ is the error term. We compare pre and post-2000 to examine the effects of the USBTA trade agreement on environmental composition of manufacturing goods. In addition to 22 industry level effects, we also used fixed effects for dirty and clean industries, using the Mani and Wheeler (1998) classification. Labor intensity is calculated by dividing total payroll expenses in an industry by the net turnover. Capital intensity is calculated by dividing the value of fixed capital by the net turnover. The variables of interest are the interaction variables that capture the increase in exports from dirty industries relative to clean industries during the liberalization period. If exports do not show an increase in dirty industries relative to cleaner industries, we would find that $\gamma_{4}=0$. The results for equation (2) are presented in Table 3.

Third, we measure the change in composition of exports using the following specification:

$$
X_{i t}=\alpha+\gamma_{1} L_{i t}+\gamma_{2} K_{i t}+\gamma 3 P_{i t}+\eta_{i}+\omega_{i t}
$$

where the right-hand side variables are defined and calculated in the same way as in equation (2). Here, the variable of interest is the coefficient on the pollution intensity variable that captures the increase in exports from dirty industries relative to clean industries. If exports from dirty industries increased at a greater rate relative to cleaner industries, we would find that $\gamma_{3}>0$. The results are presented in Table 4 .

Finally, we measure if there was a greater inflow of FDI into the dirty industries relative to the clean industries in the post-2000 years. The regression model is:

$$
F D I=\alpha+\delta_{1} F D I_{i, t-1}+\delta_{2} P_{i t}+\delta_{3} I_{i t}+\mu_{i}+\pi_{i t}
$$


Equation 4 estimates the amount of FDI inflow into manufacturing industry $\mathrm{i}$ in year $\mathrm{t}$ measured at the 2-digit VSIC level. (I) is the set of other industry level characteristics that may affect FDI inflows such as industry wise productivity and industrial tax; $\mu$ is industry fixed effects and $\pi$ is the error term. Similar to equations (1), (2) and (3), we also used fixed effects for dirty and clean industries based on the Mani and Wheeler (1998) classification. Industry wise productivity is measured by net value-added per worker. We also include we also amount of taxes paid by each industry as a control variable. The variable of interest is $\mathrm{P}$ which is the industry-wise pollution intensity. If FDI does not show an increase in dirty industries, then $\delta_{2}=0$.

\section{SAMPLE AND DATA}

Annex 1 provides a list of variables used in the industry-level analysis, unit of analysis and their data sources. Data on net turnover, industrial wages, fixed capital, foreign investment and environmental abatement cost come from the General Statistical Office (GSO) of Vietnam. Collection of these data in Vietnam is a recent exercise. As result, detailed data is not available for a longer time frame. The GSO collects these data on a yearly basis since the year 2000 through enterprise surveys and to the extent that this was the first time such an exercise has been conducted in Vietnam, the data seem fairly reliable. Although, ideally we would have liked to have data for much longer timeframe, a most comprehensive industrial survey for Vietnam is available only for the years 20002002. Since this comes on the heels of the bilateral and multilateral trade agreements, it should provide reasonable approximation of the post-openness trends in industrial production.

This data is organized by industry according to the Vietnamese Standard Industrial Classification (VSIC) ${ }^{11}$. Data on exports from Vietnam comes from the Vietnam Trade Database. This data was also organized according to the VSIC.

\footnotetext{
${ }^{11}$ The Vietnamese equivalent of ISIC is the Vietnamese Standards Industrial Classification (VSIC) which is identical to ISIC Rev. 3. ISIC - refers to the International Standard Industrial Classification. It has
} 
To measure industrial pollution intensity we use the Industrial Pollution Projection System (IPPS) developed by the World Bank. Numerous studies use the results from IPPS for studies on countries where data is insufficient ${ }^{12}$. We use the assumption that global technological constraints make some industries more polluting than others. Limitations to this assumption is discussed in Gamper-Rabindran (2001), Laplante and Meisner (2001) and Ederington and others (2004)..

To calculate the pollution load for industries in Vietnam, we first mapped the VSIC categories to the ISIC (Rev.3) codes. Using purchasing power parity between Vietnam and the U.S., we converted IPPS pollution intensities to Vietnam dollars. We deflated the output data from the General Statistical Office (GSO) and the pollution loads from IPPS to 1987-88 Vietnam prices using CPI. The steps involved in the calculation of the pollution load are detailed in Annex 2. We applied the deflated pollution load (in kg per thousand Vietnamese dollar) to output (per thousand Vietnam Dollars) to obtain the pollution intensity for each manufacturing sub-group. In the absence of actual pollution intensities from Vietnam, we are unable to verify the correspondence between the IPPS estimates and the actual pollution load of Vietnamese industries.

undergone many revisions from time to time and the latest version is Rev. 3 (1990) with ISIC Rev 3.1 in draft form. See http://esa.un.org/unsd/cr/registry/ for details.

12 See for instance Gamper-Rabindran (2001); Laplante and Meisner (2001). 
Table 1: Summary Statistics

\begin{tabular}{|l|ll|}
\hline Variable & Mean & Std Dev \\
\hline \hline Exports (in 1000 VD) & 388629.58 & 631716.97 \\
Imports (in 1000 VD) & 627066.52 & 662241.42 \\
Output (in Bn VD) & 14131.99 & 16847.36 \\
Number of enterprise & 568.38 & 757.92 \\
Total Employees & 84829.39 & 98213.65 \\
Total Labor Compensation (in Bn VD) & 899.22 & 898.52 \\
Tax & 977.55 & 1429.26 \\
Capital resource (in Bn VD) & 13280.71 & 13734.21 \\
Fixed Capital (in Bn VD) & 6954.03 & 8036.77 \\
Foreign Investment (in USD) & 440328.28 & 758084.78 \\
Expenditure of Pollution Abatement (in Bn & & \\
VD) & 19.61 & 44.73 \\
Air Pollution Intensity (kgs per VD) & 649.94 & 915.30 \\
Water Pollution Intensity (kgs per VD) & 1045.77 & 2766.07 \\
ToxicPollution Intensity (kgs per VD) & 759.16 & 877.39 \\
\hline
\end{tabular}

\section{EMPIRICAL RESULTS}

Table 2 presents the regression results from on changes in the composition of manufacturing output. The dependent variable in logged manufacturing output. Column (1) shows ordinary least square estimates, column (2) presents the results from using industry-level fixed effects, and column (3) presents the results from controlling for fixed effects between dirty and clean industries. We disaggregate pollution intensity from three media - air, water and toxic pollution intensity. Across all specifications, our regression results show that manufacturing output from more toxic pollution intensive sectors increased at a greater rate than less pollution intensive sector. Toxic pollution intensive output increased nearly 50 percent when control for fixed effects between dirty and clean industries in column (3). 
Table 2: Composition of Output

\begin{tabular}{|c|c|c|c|}
\hline $\begin{array}{l}\text { Dependent variable: } \\
\text { Ln (Output) }\end{array}$ & $\begin{array}{l}\text { (1) } \\
\text { OLS }\end{array}$ & $\begin{array}{c}\text { (2) } \\
\text { FE } \\
\text { (industry- } \\
\text { level) }\end{array}$ & $\begin{array}{c}\text { (3) } \\
\text { FE } \\
\text { (dirty/clean) }\end{array}$ \\
\hline Air Pollution & $\begin{array}{l}0.255^{* * *} \\
{[2.85]}\end{array}$ & $\begin{array}{l}0 \\
{[1.31]}\end{array}$ & $\begin{array}{l}0.381 * * * \\
{[5.10]}\end{array}$ \\
\hline Water Pollution & $\begin{array}{l}0.102^{* *} \\
{[2.06]}\end{array}$ & $\begin{array}{l}0 \\
{[0.54]}\end{array}$ & $\begin{array}{l}0.134 * * * \\
{[3.35]}\end{array}$ \\
\hline Toxic pollution & $\begin{array}{l}0.351^{* * *} \\
{[3.69]}\end{array}$ & $\begin{array}{l}0.000 * * \\
{[2.45]}\end{array}$ & $\begin{array}{l}0.531^{* * *} \\
{[6.48]}\end{array}$ \\
\hline Labor Productivity & $\begin{array}{l}-0.000 * * \\
{[2.40]}\end{array}$ & $\begin{array}{l}0 \\
{[1.35]}\end{array}$ & $\begin{array}{l}0 \\
{[1.61]}\end{array}$ \\
\hline Capital Productivity & $\begin{array}{l}0.111 \\
{[1.57]}\end{array}$ & $\begin{array}{l}0.160 * \\
{[2.00]}\end{array}$ & $\begin{array}{l}-0.002 \\
{[0.03]}\end{array}$ \\
\hline Constant & $\begin{array}{l}-7.915^{* * *} \\
{[7.63]}\end{array}$ & $\begin{array}{l}-0.939 * * * \\
{[5.70]}\end{array}$ & $\begin{array}{l}-11.867^{* * *} \\
{[11.12]}\end{array}$ \\
\hline Observations & 66 & 66 & 66 \\
\hline $\begin{array}{l}\text { R-squared } \\
\text { Number of VSIC }\end{array}$ & 0.53 & $\begin{array}{l}0.71 \\
22\end{array}$ & 0.6 \\
\hline Number of Dirty_dum & & & 2 \\
\hline
\end{tabular}

Absolute value of t statistics in brackets

* significant at 10\%; ** significant at 5\%; *** significant at $1 \%$

Descriptive analysis in Figure 3 showed that water pollution intensive output had shown the greatest percentage increase. Regression results using OLS (column 1) and fixed effects (column 3) also show that water pollution intensive output showed a positive and significant increase during this period, although the size of the coefficient on water pollution intensity is smaller than air and toxic pollution intensity. We do not find consistent results on labor and capital productivity variables.

Next, we examined the changes in composition of overall exports and changes in composition of exports in the post-USBTA period. The regression results on overall change in export composition are shown in Table 3. As in Table 2, column (1) shows 
OLS estimates, column (2) shows fixed effect estimates using industry-level fixed dummies, and column (3) show the results using dirty and clean fixed effects.

Table 3: Composition of Exports

\begin{tabular}{|l|lll|}
\hline $\begin{array}{l}\text { Dependent variable: Ln } \\
\text { (Exports as a fraction of } \\
\text { output) }\end{array}$ & \multicolumn{1}{|c}{ OLS } & $\begin{array}{c}\text { FE } \\
\text { (industry- } \\
\text { level) }\end{array}$ & $\begin{array}{c}\text { FE } \\
\text { (dirty/clean) }\end{array}$ \\
\hline \hline Air Pollution Intensity & $-0.391^{* * *}$ & 0 & $\mathbf{( 2 )}$
\end{tabular}

Absolute value of t statistics in brackets; significant at $10 \%$; ** significant at $5 \%$; *** significant at $1 \%$

The results presented in Table 3 corroborate the descriptive analysis in Figure 4. We find robust evidence that toxic pollution intensive exports increased at a greater rate relative to less pollution intensive exports. The coefficient on toxic pollution intensive exports are significant with a positive sign. On the other hand, OLS results in column (1)and fixed effects results in column (3) show that there was a negative and significant change in air pollution intensive exports during this period. Air pollution intensive exports declined by nearly 40 percent during the period of analysis. Not surprisingly, we find that labor intensive exports have shown a positive and significant increase during this period. 
Table 4 presents the results comparing the changes in export composition in the pre and post-USBTA period. In addition to the pollution intensity terms, we include an interaction term between pollution intensity variable and a dummy variable that equals 1 in post-USBTA period. If pollution intensive exports showed greater increase in postUSBTA period, we would expect the coefficient on the interaction term to be positive. Results presented in Table 4 below do not any significant results on changes in pollution intensive export in post-USBTA period compared to per-USBTA period. This is lack of evidence on export composition in post-USBTA period is, however, not surprising considering that not enough time has elapsed for there to be any noticeable changes in production capabilities and export patterns. Perhaps, a similar analysis conducted after a few more years may reveal a different pattern. On the other hand, we do find noticeable, significant increases in overall export pollution (toxic) intensity in Table 3. 
Table 4: Composition of Exports in the Post-USBTA Period

\begin{tabular}{|c|c|c|c|}
\hline $\begin{array}{c}\text { Dependent variable: } \mathrm{Ln} \\
\text { (Exports as a fraction of } \\
\text { output) }\end{array}$ & $\begin{array}{c}\text { (1) } \\
\text { OLS }\end{array}$ & $\begin{array}{c}\text { FE (industry- } \\
\text { level) }\end{array}$ & $\begin{array}{c}(3) \\
\text { FE } \\
\text { (dirty/clean) } \\
\end{array}$ \\
\hline \multirow[t]{2}{*}{ Air Pollution Intensity } & $-0.422 * * *$ & 0.00 & $-0.417 * * *$ \\
\hline & {$[2.84]$} & [.] & [2.78] \\
\hline \multirow[t]{2}{*}{ Water Pollution Intensity } & 0.093 & 0.00 & 0.09 \\
\hline & {$[1.36]$} & [.] & {$[1.30]$} \\
\hline \multirow[t]{2}{*}{ Toxic Pollution Intensity } & $0.325^{* *}$ & $0.806^{* *}$ & $0.356^{*}$ \\
\hline & {$[2.01]$} & {$[2.22]$} & {$[1.91]$} \\
\hline \multirow[t]{2}{*}{ Labor Intensity } & $10.125^{* * *}$ & 2.854 & $9.903 * * *$ \\
\hline & [3.17] & {$[0.22]$} & {$[3.02]$} \\
\hline \multirow[t]{2}{*}{ Capital Intensity } & 0.182 & -0.029 & 0.288 \\
\hline & {$[0.31]$} & {$[0.02]$} & {$[0.44]$} \\
\hline \multirow{3}{*}{$\begin{array}{l}\text { Air Pollution * Trade } \\
\text { Liberalization dummy }\end{array}$} & 0.00 & 0.00 & 0.00 \\
\hline & & & \\
\hline & {$[0.59]$} & {$[0.63]$} & {$[0.54]$} \\
\hline \multirow{3}{*}{$\begin{array}{l}\text { Water Pollution * Trade } \\
\text { Liberalization dummy }\end{array}$} & 0.00 & 0.00 & 0.00 \\
\hline & & & \\
\hline & {$[0.48]$} & {$[0.11]$} & {$[0.46]$} \\
\hline \multirow{3}{*}{$\begin{array}{l}\text { Toxic Pollution * Trade } \\
\text { Liberalization dummy }\end{array}$} & 0.00 & $0.00 *$ & 0.00 \\
\hline & & & \\
\hline & {$[0.00]$} & {$[1.78]$} & {$[0.01]$} \\
\hline \multirow[t]{2}{*}{ Constant } & $-2.790 * * *$ & 4.962 & $-3.110 * *$ \\
\hline & {$[2.91]$} & [1.39] & {$[2.30]$} \\
\hline Observations & 132 & 132 & 132 \\
\hline R-squared & 0.21 & 0.09 & 0.21 \\
\hline Number of Dirty_dum & & & 2 \\
\hline Number of VSIC & & 22 & \\
\hline
\end{tabular}

Absolute value of $\mathrm{t}$ statistics in brackets

significant at $10 \%$; ** significant at $5 \%$; *** significant at $1 \%$

Finally, an interesting aspect of trade liberalization in Vietnam in that last few years has been the amount of FDI that has come in. A variant of the trade-environment debate argues that in developing countries, foreign investors are more likely to invest in pollution intensive sectors to take advantage of the cost difference in environmental 
compliance costs between developed and developing countries. To examine whether foreign investments in Vietnam are more attracted to the pollution intensive sectors, we examined the pollution intensity of FDI. Table 5 presents the results on the composition of foreign investments. Column (1) shows the OLS estimates and column (2) shows fixed effect estimates using dirty and clean dummies. The dependent variable is log industry-level foreign investment.

Table 5: Composition of Foreign Direct Investments

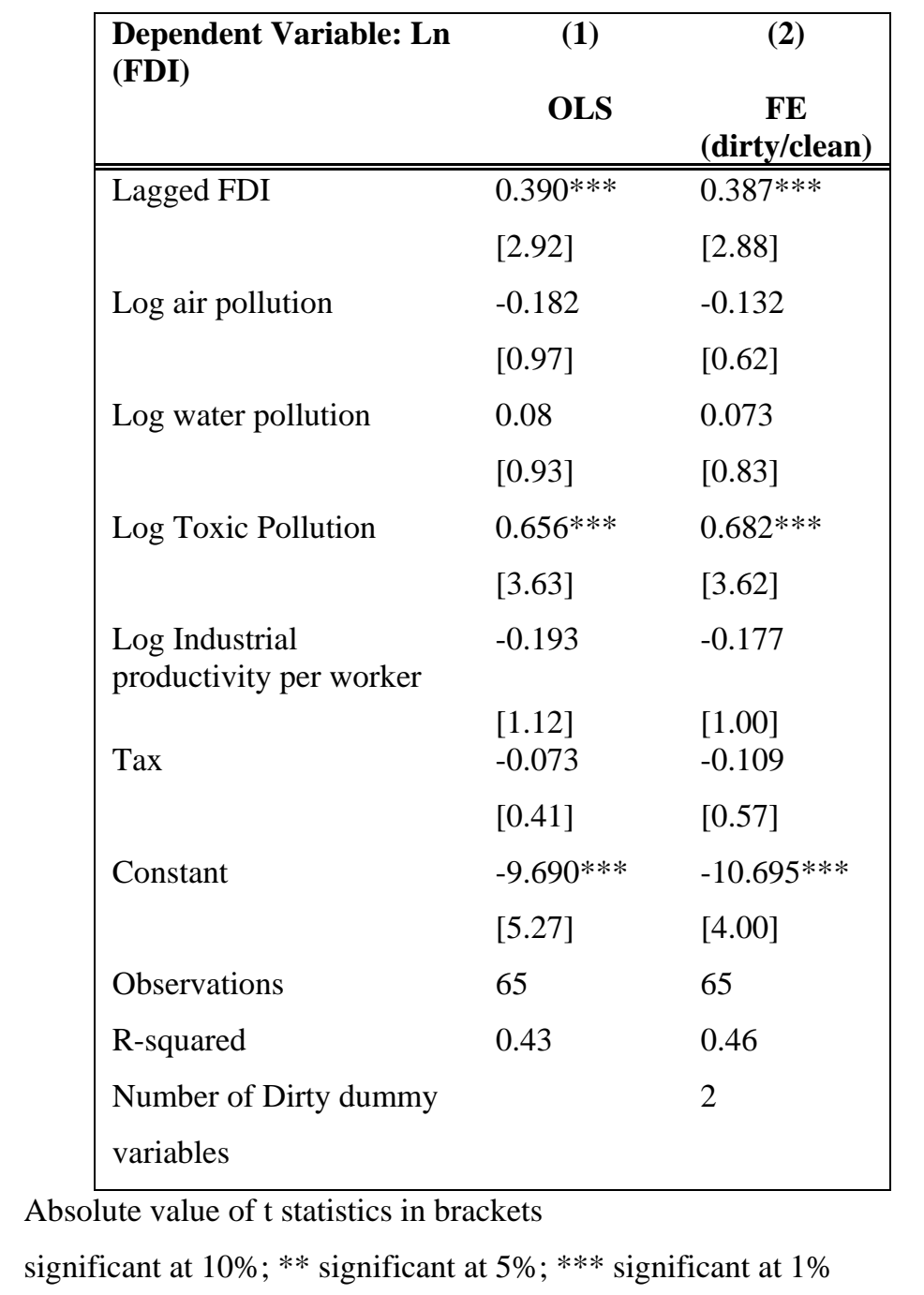

We find that FDI is significantly higher in toxic pollution intensity sectors. The coefficient on toxic pollution intensive FDI is $0.65^{* * *}$ in column (1) and $0.68^{* * *}$ in column (2) indicating that foreign investment was more attracted to toxic pollution intensive sectors in Vietnam. The coefficients on air and water pollution intensity are not 
significant. Lagged FDI (lagged by one period) is a significant predictor of current FDI. None of the other determinants of FDI (including industrial productivity and tax rate) are found to be significant.

\section{CONCLUSIONS}

Vietnam's integration with the international economy has increased significantly over the past decade, aided by substantial liberalization of trade, and appears set to increase further as trade-expanding measures (AFTA, the USBTA) take full effect. This rather dramatic shift in Vietnam's trading patterns has important implications for the environment and use of natural resources. Though the precise environmental impacts of the various bilateral, regional, or multilateral trade liberalization programs undertaken are often difficult to anticipate, this paper offers a more systematic analysis of the trading and investment patterns to give a broader understanding of the environmental implications of greater openness of the economy during the last decade.

We conclude from our analysis that there has been a change in composition of output in Vietnam that parallels the gradual opening up of the economy. Manufacturing output has been significantly higher from the water pollution intensive sectors compared to the less pollution intensive sectors. We also find consistently robust results that indicate that exports in Vietnam have increased significantly from the toxic pollution intensive sectors and foreign direct investments have been higher in the toxic pollution intensive sectors. This story is, on the surface, is consistent with what one would expect looking at the trend of Vietnamese production and exports, though Vietnam still remains a net importer of pollution-intensive goods.

There are several caveats with this study. First, the time period of our analysis is 2000 to 2003 in the case of output and FDI, 1997 to 2003 in the case of exports. This is a relatively small time frame to observe long-term changes in the composition of industries. The results we observe could be an initial level effect, a big initial burst of structural change due to the economy being largely closed and relative prices distorted for such a long time. Thus, after the initial sharp changes, the reallocations may not 
continue. Secondly, in the absence of pollution intensity data from Vietnam, we have used pollution measures from the U.S. as proxies (as suggested by previous IPPS studies). Should pollution intensity data from Vietnam become available, it would be useful to re-examine the issue using Indian measures of pollution intensities.

Despite these caveats, this study has highlighted important gaps in the environmental policy implementation in Vietnam and enables us to make useful recommendations. In order to make specific policy recommendations on future steps, we need to identify the manufacturing sectors that have resulted in greatest increase in water pollution intensive output and toxic pollution intensive exports. Annex 3 shows the important water pollution intensive sectors as: iron and steel, non-ferrous metals, industrial chemicals, rubber and leather products. These sectors are also considered significant contributors for toxic pollution (in addition to ceramics) and consistently rank high based on the Linear Acute Human Toxic Intensity (LAHTI) ${ }^{13}$. Analyses of Vietnamese exports shows that the sectors have shown highest increase in exports are: textile (91 percent), leather (49 percent), and rubber products (26 percent) ${ }^{14}$. Of these the textile industry is also large consumer for industrial chemicals. Therefore, increased textiles exports seems to have also fueled a simultaneous increase in industrial chemicals. Similarly, export revenues from craft villages have increased significantly in recent years to the tune of almost half a billion US dollars a year. These are again a major sources of toxic and water pollution. It is thus not surprising to note that Vietnam's exports are getting dirtier over time since its export specialization has moved away from more tradition oil and other primary commodities towards manufacturing especially leather and textile industries. The results also suggest that foreign direct investment in Vietnam reflects a similar trend with toxic intensive heavy and light industries attracting most FDI.

These findings suggest that while trade liberalization measures have been pursued to promote economic growth in Vietnam, they have led to some potentially adverse environmental consequences. These results suggest that there is a trade-off between the

\footnotetext{
${ }^{13}$ Wheeler, et. al. (1994)

${ }^{14}$ Source: International Trade Statistics, ITC: http://www.intracen.org/menus/countries.htm
} 
economic gains from liberalization and the environmental consequences from a liberalization episode that has not been accompanied by a simultaneous strengthening of environmental policies. This paper highlights the need to consider strengthening environmental policies at the time when further trade liberalization is being contemplated through WTO. This calls for further improvements in environmental standards in the specific growth industries identified, to protect natural assets and public health, and to assure foreign investors concerned about corporate responsibility, particularly for the future development of the industrial and agricultural sectors. 


\section{REFERENCES}

Auffret, Philippe (2003). “Trade Reform in Vietnam: Opportunities with Emerging Challenges”, World Bank Policy Research Group Working Paper \#3076.

Athukorala, Prema Chandra (2005). "Trade Policy Reform and the Structure of Protection in Vietnam” Forthcoming in World Economy.

Copeland, Brian R., and M. Scott Taylor (2003). International Trade and Environment: Theory and Practice, Princeton University Press, Princeton.

Ederington, Josh, Arik Levinson and Jenny Minier (2004). "Trade Liberalization and Pollution Havens,” Advances in Economic Analysis and Policy, Vol. 4, Issue 2, The B.E. Journals in Economic Analysis and Policy.

Gamper-Rabindran, Shanti, and Shreyasi Jha. (2004) "Environmental Impact of India's Trade Liberalization" University of North Carolina at Chapel Hill, Department of Public Policy Working Paper.

Gamper-Rabindran, Shanti (2001). "Did Mexico’s Dirty Production Grow post-NAFTA? What can the data tell us? In Essays on Empirical Environmental Economics, Ph.D. thesis, Dept of Economics, MIT.

Hettige, Hemamala, Paul Martin, Manjula Singh, and David Wheeler, “The Industrial Pollution Projection System”, Policy Research Working Paper \#1431, The World Bank.

Institute of Economics (2002). The Nominal and Effective Rates of Protection by Industry in Vietnam: a tariff-based assessment, Hanoi: Institute of Economics.

International Monetary Fund (2003). "External Trade Policy, Performance and Competitiveness," in Selected Issues, IMF Country Report No. 03/381, December 2003. Washington, D.C.: IMF.

International Trade Statistics, ITC: http://www.intracen.org/menus/countries.htm

Laplante, Benoit, and Craig Meisner (2001). "Estimating Conventional Industrial Water Pollution in Thailand”, World Bank Working Paper. Washington, D.C.: World Bank.

Mani, Muthukumara, and David Wheeler (1998). "In search of pollution havens? Dirty Industry in the World Economy,1960-1999", Journal of Environment and Development, Vol. 7, No. 3, September 1998, pp 215-247. 
Mani, Muthukumara S. (1996), "Environmental Tariffs on Polluting Imports: An Empirical Study,” Environmental and Resource Economics, 7, 391-411.

Matin, Kazi, Rajapatirana, Sarath and Prema Chandra Athukorla (2002). "Vietnam: Deepening Reform for Rapid Export Growth”. World Bank (mimeo). Washington, D.C.: World Bank.

Robison, D.H. (1998), “Industrial Pollution Abatement: The Impact on Balance of Trade,” Canadian Journal of Economics, 21, 702-706.

Tobey, James A. (1990), “The Effects of Domestic Environmental Policies on Patterns of World Trade: An Empirical Test,” Kyklos, 43(2), 191-209.

World Bank (1999). Trade, Global Policy and Environment, World Bank Discussion Paper No. 402, Washington, D.C.: World Bank.

World Bank (2000). Greening Industry: New Roles for Communities, Markets and Governments. Washington, D.C.: World Bank

World Bank (2002). Vietnam’s Exports: Policies and Prospects, Hanoi: World Bank Vietnam (draft report).

WTO (2004). Trade and Environment at the WTO: Background Document. Geneva:WTO. 


\section{Annex 1: Data Table and Code Book}

\begin{tabular}{|c|c|c|}
\hline Variable Label & Description & Unit \\
\hline VSIC & $\begin{array}{l}\text { Vietnam Standards Industrial } \\
\text { Classification matches the ISIC } \\
2 \text { digit Rev } 3\end{array}$ & 2 digit \\
\hline year & & $2000-2002$ \\
\hline number_enterprise & Number of Enterprises & \\
\hline total_labor_compensation & $\begin{array}{l}\text { Total compensation of } \\
\text { employees }\end{array}$ & Billion VND \\
\hline comps_health_ins_union & $\begin{array}{l}\text { Total contributions of } \\
\text { enterprises to insurance, health, } \\
\text { and trade unions }\end{array}$ & Billion VND \\
\hline Lab_prod & Net turnover per employee & \\
\hline Cap_Prod & $\begin{array}{l}\text { Net turnover per unit of fixed } \\
\text { capital }\end{array}$ & \\
\hline total_employees & Total employees & \\
\hline Capital & Capital resource & Billion VND \\
\hline fixed_cap & $\begin{array}{l}\text { Fixed asset and } \\
\text { long-term investment }\end{array}$ & Billion VND \\
\hline output & Net turnover & Billion VND \\
\hline $\operatorname{tax}$ & Tax and fees paid & Billion VND \\
\hline FDI & $\begin{array}{l}\text { Legal Capital Invested by } \\
\text { foreign enterprises }\end{array}$ & USD \\
\hline FDI_perctotalca & $\begin{array}{l}\text { Proportion of FDI in total } \\
\text { invested capital: FDI/total } \\
\text { capital }\end{array}$ & \\
\hline RND & R\&D Investment of Enterprises & Billion VND \\
\hline env_abatement_cost & $\begin{array}{l}\text { Total costs of enterprise spent } \\
\text { for environmental protection } \\
\text { during the year }\end{array}$ & Billion VND \\
\hline amt_spent_on wastetreatmentequipt & $\begin{array}{l}\text { Amount spent for construction, } \\
\text { equipment for waste treatment }\end{array}$ & Billion VND \\
\hline Exports & & 1000 USD \\
\hline Imports & & 1000 USD \\
\hline NetEx & & 1000 USD \\
\hline Air Pollution & $\begin{array}{l}\text { Average of SOX, NOX, CO, } \\
\text { Particulate Matter }\end{array}$ & Kgs/million VD \\
\hline Water Pollution & Average of BOD and TSS & Kgs/million VD \\
\hline Toxic Pollution & & Kgs/million VD \\
\hline
\end{tabular}




\section{Annex 2: Steps to Calculate Pollution Intensity for Vietnam}

1. Get Pollution Intensity at the 2 digit ISIC Re. 3 level

2. Merge with VSIC 2 digit to get the output variable

3. Convert IPPS pollution intensities into Vietnamese Currency: In 1987-88, VD 78.3 = 1 USD (Source: IMF: International Financial Statistics).

We divide pollution intensities (unit of measure for PI is Kgs/per 1,000,000 USD) by 78.3 to give us kilograms (of air pollution, water pollution and toxic pollution) per million Vietnamese currency in 1987-88.

Inflate PI data to 2000 prices - We use official consumer price index (CPI) for the entire country. The base year of CPI is 1995 (1995=100).

1987-88 CPI $(1995=100)=2.3$

2000-2001 CPI $(1995=100)=120$

We use [120/2.3] $=52.2$ as the inflation factor to obtain pollution intensities in 2000 Vietnamese currency.

\section{Steps to Calculate the Deflation Factor for 1997-2002}

CPI for $1997=109$

CPI for $1998=109$

CPI for $1999=109$

CPI for $2000=120$

CPI for $2001=119$

CPI for $2001=124$

(Source: IMF - International Financial Statistics)

We convert all variables to 2000 prices. So the deflation factors for every year are as follows:

CPI for $1997=1.1$

CPI for $1998=1.02$

CPI for $1999=0.98$

CPI for $2000=1$

CPI for $2001=0.96$

CPI for $2001=1.008$ 


\section{Annex 3: Ranking of Dirtiest Manufacturing Industries}

A conventional approach in the literature to define dirty industries has been to identify pollution-intensive sectors as those that have incurred high levels of abatement expenditure per unit of output in the United States and other OECD economies (Mani, 1996; Robison, 1988; Tobey 1990). By this criterion, five sectors emerge as leading candidates for dirty industry status; iron and steel, nonferrous metals, industrial chemicals, pulp and paper and nonmetallic mineral products. ${ }^{15}$

Another, more direct, approach is to select sectors that rank high on actual emissions intensity (emissions per unit of output). Mani and Wheeler (1998) have determined the high-ranking sectors by this criterion using detailed emissions intensities by medium U.S. manufacturing at the three-digit Standard Industrial Classification (SIC) level. They have then computed average sectoral rankings for conventional air pollutants, water pollutants, and toxics (heavy metals) as shown in the Table. Again, five of the six sectors with highest overall ranks are iron and steel, nonferrous metals, industrial chemicals, pulp and paper, and nonmetallic mineral products. ${ }^{16}$ The strength of this approach lies in the fact that the set of dirtiest manufacturing industries using this approach appears to be fairly stable across countries and pollutants.

\begin{tabular}{|c|c|c|c|c|}
\hline Rank & Air & Water & Toxic/Metal & Overall \\
\hline 1 & Iron and Steel & Iron and Steel & Non-Fer Metals & Iron and Steel \\
\hline 2 & Non-Fer Metals & Non-Fer Metals & Iron and Steel & Non-Fer Metals \\
\hline 3 & Non-fer minerals & Pulp and paper & $\begin{array}{l}\text { Industrial } \\
\text { Chemicals }\end{array}$ & $\begin{array}{l}\text { Industrial } \\
\text { Chemicals }\end{array}$ \\
\hline 4 & Petro Coal Prod & Mis Minerals & Leather Products & Petro Refineries \\
\hline 5 & Pulp and paper & Industrial Chemicals & Pottery & Non-fer minerals \\
\hline 6 & Petro Refineries & Other Chemicals & Metal Products & Pulp and paper \\
\hline 7 & $\begin{array}{l}\text { Industrial } \\
\text { Chemicals }\end{array}$ & Beverages & Rubber Products & Other Chemicals \\
\hline 8 & Other Chemicals & Food Products & Electrical products & Rubber Products \\
\hline 9 & Wood Products & Rubber Products & Machinery & Leather Products \\
\hline 10 & Glass products & Petro Products & Non-Met Minerals & Metal Products \\
\hline
\end{tabular}

Source: Mani and Wheeler (1998)

\footnotetext{
${ }^{15}$ Petroleum is usually excluded because a very few countries are actually involved in its production.

${ }^{16}$ While textiles do not figure here in the list, garment industries with their backward linkage sectors like composite textile mills (including dyeing printing \& finishing units), and leather-processing units use substantial quantities of highly toxic dyes and chemicals. Some of these industries asituated close to the rivers dispose of their toxic wastes there. Tanneries and some other textile finishing units, situated in land locked areas, also pose increasing pollution problems to the surroundings.
} 